\title{
A BRITISH VIEW TO AN AMERICAN WAR: WHITMAN'S “DRUM-TAPS” CLUSTER AND THE EDITORIAL INFLUENCE OF WILLIAM MICHAEL ROSSETTI
}

JULIANNE RAMSEY

WHITMAN SCHOLARS HAVE long been acquainted with the sequence of events and social concerns leading up to William Michael Rossetti's 1868 London anthology of poems "selected" from the 1867 edition of Leaves of Grass. ${ }^{1}$ However, no investigation has yet been launched to determine whether and in what way the hand of the celebrated British editor-critic may still imprint some portion of the final structure and meaning of Leaves of Grass itself. Rossetti's selection process necessitated regrouping the materials of the highly unstructured 1867 Leaves $^{2}$ into five new thematic "clusters" of his own configuration, including for the first time a "Drum-Taps" cluster of Civil War poems that predates Whitman's own grouping of the same title within the body of the 1871 Leaves edition. The lack of sequential pattern or thematic coherence in Whitman's original Drum-Taps and Sequel to Drum-Taps volume of 1865 is itself noted by Betsy Erkkila, who observes that "the disruption of the war is . . . apparent: The poems are characterized by radical shifts in style, theme, and mood, as Whitman seeks an appropriate poetic posture in relation to the whirl and din, fracture and chaos of the first modern war." By significant comparison, she draws attention to the "final ordering of the Drum-Taps cluster in the 1881 Leaves," within which the poet "molds the 'convulsiveness' of the war into a providential scheme," a marked pattern of orderly movement which evolves from the first "militant exultation" to "the actual experience of suffering and death, to demobilization and the final justification of the war" as vindication for democracy in America and the world. ${ }^{3}$ What is yet to be examined is the evidence that Whitman himself borrowed this suggestive "providential" sequence for the "Drum-Taps" cluster from Rossetti's 1868 anthology, given the tellingly similar ordering of these newly regrouped poems in the 1871 Leaves, the format of which Whitman expanded and slightly rearranged for the 1881 "definitive" configuration. ${ }^{4}$ The underlying structure of the "Drum-Taps" sequence itself remains Rossetti's, who provided the viewpoint, the thematic "cycle of war" 
pattern by which Whitman is taken to have interpreted the American civil upheaval.

Out of 236 poems contained in the 1867 "primary issue" of Leaves, Rossetti selected 103 for his anthology, comprising somewhat less than half of the available Whitman poems both numerically and in terms of textual bulk; Rossetti's editorial pruning was even more rigorous for his new "Drum-Taps" cluster, which retains 28 carefully chosen selections out of 71 poems in the combined Drums-Taps and Sequel materials, a trim-down here motivated essentially by concerns for thematic coherence. As remarked by Harold W. Blodgett and Sculley Bradley, the 1865 volume "was not limited to war poems," insofar as "at least 20 of the 71 poems in Drum-Taps and the "Sequel" have "nothing to do with the theme suggested by the title." ${ }^{5}$ Not only were "civilian" topics liberally mixed into the initial Drum-Taps/Sequel texts, but "war" poems were usually sited together without regard to any consistent thematic pattern. For example, in the original Drum-Taps the vigorous public militarism of "Beat! Beat! Drums!" is immediately followed by the intimate

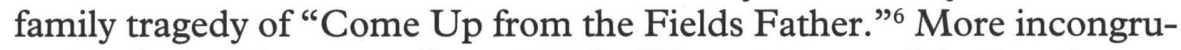
ously, the passionate realism of "The Wound-Dresser" is directly succeeded by the personal lyricism of "When I Heard the Learn'd Astronomer," not by any stretch of interpretation a military poem. And in the Sequel a reader moves from the highly conventional memorial of "O Captain! My Captain!" to the mystical demobilization of "Spirit whose Work is Done" to the entirely unrelated religious exploration, "Chanting the Square Deific." Blodgett and Bradley report additionally that "of the 53 Drum-Taps poems of 1865, only 29 are retained in the final 1881 grouping; and of the 18 poems of the 'Sequel,' only 9 are retained." Comparatively, Rossetti's 1868 cluster contains 22 Drum-Taps poems, 6 from the Sequel, almost all of which reappear in Whitman's 1881 configuration to provide the structure and sequence on which he (later) expanded. While these commentators note that Whitman eventually "attained a concentration not before achieved" in this cluster, the tightened focus must itself be directly credited to Rossetti's intervening editorial craftsmanship.

To begin assessing the impact of Rossetti's editorial influence on the "Drum-Taps" cluster, we must determine through a series of comparative charts those poems of Whitman's initial 1865 "sequence" for Drum-Taps/Sequel which the British editor selected and rearranged into the "cycle of war" thematic pattern. The 1865/67 groupings will be listed by (definitive) title and numbered by position in the ordering; those poems chosen by Rossetti will be highlighted and cross-referenced "(R\#)" according to position in his own sequencing: 
(R1) 1. First O Songs for a Prelude

2. Shut not Your Doors

3. Cavalry Crossing a Ford

(R5) 4. Song of the Banner at Daybreak

(R6) 5. By the Bivouac's Fitful Flame

(R2) 6. Eighteen Sixty-One

7. From Paumanok Starting I Fly like a Bird

8. Beginning My Studies

9. The Centenarian's Story

10. Pioneers! O Pioneers!

11. Quicksand Years

(R14) 12. The Wound-Dresser

13. When I Heard the Learn'd Astronomer

(R3) 14. Rise O Days from Your Fathomless Deeps

15. A Child's Amaze

(R4) 16. Beat! Beat! Drums!

(R15) 17. Come Up from the Fields Father

(R8) 18. City of Ships

19. Mother and Babe

(R9) 20. Vigil Strange I Kept on the Field One Night

(R10) 21. Bathed in War's Perfume

(R11) 22. A March in the Ranks Hard-Prest, and the Road Unknown

23. Long, too Long America

(R12) 24. A Sight in Camp in the Daybreak Gray and Dim

25. A Farm Picture

(R19) 26. Give Me the Splendid Silent Sun

(R20) 27. Over the Carnage Rose Prophetic a Voice

28. To a Certain Civilian

29. Year of Meteors

30. The Torch

31. Years of the Modern

32. Year that Trembled and Reel'd Beneath $\mathrm{Me}$

(R17) 33. The Artilleryman's Vision

(R18) 34. O Tan-Faced Prairie-Boy

(R22) 35. Camps of Green

(R13) 36. As Toilsome I Wander'd Virginia's Woods

(R25) 37. Ashes of Soldiers

38. The Ship Starting

39. A Broadway Pageant

40. Thick-Sprinkled Bunting

41. Old Ireland

42. Look Down Fair Moon

43. Out of the Rolling Ocean the Crowd

44. World Take Good Notice

45. I Saw Old General at Bay

46. Others may Praise What They Like

47. Solid, Ironical, Rolling Orb

48. Hush'd be the Camps To-day

49. Weave in, My Hardy Life

50. Turn O Libertad

(R7) 51. Bivouac on a Mountain Side 
1865/67 Sequel to Drum-Taps

(R26)

1. When Lilacs Last in the Dooryard Bloom'd

2. Race of Veterans

3. O Captain! My Captain!

4. Spirit whose Work is Done

5. Chanting the Square Deific

6. I Heard You Solemn-Sweet Pipes of the Organ

7. Not my Enemies Ever Invade Me

8. O Me! O Life!

9. Ah Poverties, Wincings, and Sulky Retreats

10. As I Lay with My Head in Your Lap Camerado

11. This Day, O Soul

(R16) 12. Old War-Dreams

13. An Army Corps on the March

(R23) 14. Dirge for Two Veterans

(R24) 15. How Solemn as One by One

16. Lo, Victress on the Peaks

(R27) 17. Reconciliation

(R28) 18. To the Leaven'd Soil They Trod

Rossetti only rarely preserves pairings (one triad) of poems from Whitman's original Drums-Taps/Sequel ordering; his selection is far more conspicuous for the items dropped, the "gaps" produced and then pulled together with rearrangements of the accepted choices into a new, distinct pattern of six thematic "sub-sequences." We will next chart the complete Rossetti sequence of 1868 , breaking his selections into the six sub-units that contribute to the "cycle of war" plan; each poem is likewise numbered by position in the new cluster and cross-referenced "(DT\#)" or "(SD\#)" according to its original placement in the DrumTaps or Sequel to Drum-Taps of 1865/67:

(DT6) 2. Eighteen Sixty-One

(DT14) 3. Rise O Days from Your Fathomless Deeps

(DT16) 4. Beat! Beat! Drums!

(DT4) 5. Song of the Banner at Daybreak

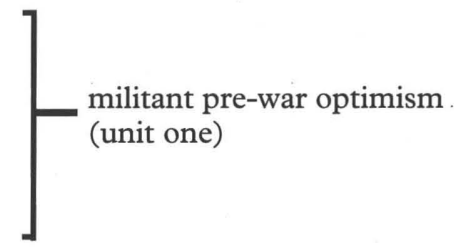


(DT20) 9. Vigil Strange I Kept on the Field One Night

(DT21) 10. Bathed in War's Perfume

(DT22) 11. A March in the Ranks Hard-Prest, and the Road Unknown

(DT24) 12. A Sight in Camp in the Daybreak Gray and Dim

(DT36) 13. As Toilsome I Wander'd Virginia's Woods

(DT12) 14. The Wound-Dresser

(DT17) 15. Come Up from the Fields Father

(SD12) 16. Old War-Dreams

(DT33) 17. The Artilleryman's Vision

(DT34) 18. O Tan-Faced Prairie-Boy

(DT26) 19. Give Me the Splendid Silent Sun

(DT27) 20. Over the Carnage Rose Prophetic a Voice

(DT52) 21. Pensive on Her Dead Gazing

(DT35) 22. Camps of Green

(SD14) 23. Dirge for Two Veterans

(SD15) 24. How Solemn as One by One

(DT37) 25. Ashes of Soldiers

(SD4) 26. Spirit whose Work is Done

(SD17) 27. Reconciliation

(SD18) 28. To the Leaven'd Soil

They Trod

maturity in direct war experience with death/suffering

(unit three) war memories and

retrospective yearning for peace

(unit four) mystical vindication in death for democracy

(unit five)

The complex cross-postings between the 1865/67 and 1868 "DrumTaps" configurations indicate that the sequencing we will soon trace forward into the 1871 and 1881 Leaves editions is not Whitman's spontaneous production out of formlessness but rather the original reconstruction of Rossetti's editorial interposition. The overall thematic sequence itself follows a logical-poetic progression of meaningful "units" that move through a consecutive "cycle of war" succession:

1. youthful enthusiasm and optimistic war preparation (patriotic "saber-rattling");

2. pre-combat pensive "tone-poems" that suggest mobilization in the field and the tension of coming battle;

3. direct personal experience of death and suffering in war, with heightened spiritual maturity;

4. post-combat memories and assessments, with yearning for the war's completion and the gifts of peace; 
5. vindication of democracy in death and the war's mystical justification;

6. demobilization and consummation of national reconciliation.

This tightly controlled sequencing admirably expresses the essence of the American war experience, with each individual poem contributing to its respective "unit" of meaning through a shared context of interaction among other poems similarly communicating the idea of their specific segment.

In the 1871 Leaves, Whitman repeats Rossetti's thematic-pattern sequence, except for conflating and reordering the earlier fourth and fifth "units" by transferring four poems from the 1868 configuration into the initial cluster, "Ashes of Solders," that opens his new volume of esoteric theodicy, Passage to India; it is understandable that Whitman would select for inclusion in that work those of his war poems that most directly address the "metaphysics of death." The poet transfers only two other selections from Rossetti's "Drum-Taps" grouping, with these moved into his new flag-oriented cluster, "Bathed in War's Perfume." Thus, Whitman retains twenty-two of Rossetti's original twenty-eight entries, nearly all of these still appearing in the thematic "unit" first established by the British editor and most poems in much the same order of presentation within these units. Variations occur primarily through Whitman's interpolation of ten poems (many of which voice his personal role as "bard of democracy") which Rossetti did not include in his own space-limited anthology, so that the 1871 "DrumTaps" cluster comprises thirty-two entries total. As before stated, Rossetti's editing provides the structural and thematic "backbone" of meaning against which Whitman posted his own relatively minor modifications.

In charting these developments, the 1868 and 1871 "Drum-Taps" clusters with their respective sequencings will be compared unit by unit; transfers to "Ashes of Soldiers" and "Bathed in War's Perfume" will be suitably designated "(AS)" or "(BWP)" with interpolations from the 1867 materials indicated by "(DT\#)/(SD\#)" or as appropriate:

Rossetti's 1868 Cluster

pre-war optimism:

First O Songs for a Prelude

Eighteen Sixty-One

Rise O Days from Your Fathomless Deeps

Beat! Beat! Drums!
Whitman's 1871 Cluster

First O Songs for a Prelude

Eighteen Sixty-One

Beat! Beat! Drums!

From Paumanok Starting I Fly like a Bird (DT7)

Rise O Days from Your Fathomless Deeps 
pre-war pensiveness:

An Army Corps on the March (SD13)

By the Bivouac's Fitful Flame Cavalry Crossing a Ford (DT3) Bivouac on a Mountain Side City of Ships

Bivouac on a Mountain Side

By the Bivouac's Fitful Flame

mature war experience:

Vigil Strange I Kept on the Field One Night Bathed in War's Perfume (BWP)

A March in the Ranks Hard-Prest, and the Road Unknown

A Sight in Camp in the Daybreak Gray and Dim

As Toilsome I Wander'd Virginia's Woods

The Wound-Dresser

Come Up from the Fields Father
Come Up from the Fields Father

Vigil Strange I Kept on the Field One Night

A March in the Ranks Hard-Prest, and the Road Unknown

A Sight in Camp in the Daybreak Gray and Dim

Not the Pilot (insert from 1867 Leaves proper)

As Toilsome I Wander'd Virginia's Woods

Year that Trembled and Reel'd

Beneath Me (DT32)

The Wound-Dresser

memory and democratic vindication:

Old War-Dreams (AS)

The Artilleryman's Vision

O Tan-Faced Prairie-Boy

Give Me the Splendid Silent Sun

Over the Carnage Rose Prophetic a Voice

Pensive on Her Dead Gazing (AS)

Camps of Green (AS)

Dirge for Two Veterans

How Solemn as One by One

Ashes of Solders (AS)
Long, too Long America (DT23)

Give Me the Splendid Silent Sun

Dirge for Two Veterans

Over the Carnage Rose

Prophetic a Voice

The Artilleryman's Vision

I Saw Old General at Bay (DT45)

O Tan-Faced Prairie-Boy

Look Down Fair Moon (DT42)

demobilization and reunification:

Spirit whose Work is Done

Reconciliation

To the Leaven'd Soil They Trod
Reconciliation

Spirit whose Work is Done How Solemn as One by One Not Youth Pertains to Me (DT53) To the Leaven'd Soil They Trod

Whitman's definitive "Drum-Taps" cluster of 1881 includes all those selections appearing in the 1871 sequencing in very similar order of presentation, except with the addition of eleven new interpolations, so that the earlier configuration of thirty-two poems has expanded to a final grouping of forty-three. Nearly all of these insertions result from 
Whitman's transfers out of two of his 1871 clusters disbanded for the 1881 Leaves edition, "Marches now the War is Over" and "Bathed in War's Perfume," with most of these interpolations from the defunct clusters moved into the last two sequence-units of "Drum-Taps." These former groupings of poems contained meditations on the democratic future and national self-respect, which found a logical placement in those "Drum-Taps" thematic units that address post-war political assessment and American reunification.

The first three 1881 "Drum-Taps" units remain virtually unchanged from their 1871 configurations. The first 1881 segment devoted to prewar optimism retains all 1871 poems in their earlier ordering; the only modification concerns two interpolated poems. These are "Song of the Banner at Daybreak" (a transfer from the "Bathed in War's Perfume" cluster) now inserted between "From Paumanok Starting I Fly like a Bird" and "Rise O Days from Your Fathomless Deeps" (also here reoccupying the fifth position in the overall "Drum-Taps" sequence as originally designed by Rossetti); then "Virginia-The West," an 1872 poem appearing in that year's volume As a Strong Bird on Pinions Free, now situated between "Rise O Days" and "City of Ships." The second unit of pensive "tone-poems" contains exclusively the same set of selections as in 1871, except that in 1881 "An Army Corps on the March" is moved to appear between "Bivouac on a Mountain Side" and "By the Bivouac's Fitful Flame." Likewise, the third unit concerning direct war experience remains precisely the same in 1871 as in 1881, save for the switching of positions of "Not the Pilot" and "As Toilsome I Wander'd Virginia's Woods" (a reversion to Rossetti's 1868 ordering in relation to "A Sight in Camp in the Daybreak Gray and Dim" preceding "As Toilsome I Wander'd").

The interpolations into the final two units and occasional shifts in earlier poem sequencing are again best delineated by charting the respective configurations of 1871 and 1881 for comparison. Insertions from the cluster "Marches now the War is Over" will be designated "(MWO)" as well as "(BWP)" or "(AS)" for poems carried over from the disbanded clusters "Bathed in War's Perfume" or "Ashes of Soldiers." Those poems newly introduced into the "Drum-Taps" cluster that originate in the 1865 Drum-Taps/Sequel volume will be further denominated by symbols previously established for this study or indicated by direct statement if transferred from another source:

$$
\text { “Drum-Taps" } 1871 \text { "Drum-Taps" } 1881
$$

memory and democratic vindication:

Long, too Long America

Give Me the Splendid Silent Sun

Dirge for Two Veterans
Long, too Long America

Give Me the Splendid Silent Sun

Dirge for Two Veterans 
Over the Carnage Rose Prophetic a Voice

The Artilleryman's Vision

I Saw Old General at Bay

O Tan-Faced Prairie-Boy

Look Down Fair Moon

Reconciliation

Spirit whose Work is Done

How Solemn as One by One

Not Youth Pertains to $\mathrm{Me}$

To the Leaven'd Soil They Trod
Over the Carnage Rose Prophetic a Voice

I Saw Old General at Bay

The Artilleryman's Vision

Ethiopia Saluting the Colors (BWP)

Not Youth Pertains to $\mathrm{Me}$

Race of Veterans (MWO) (SD2)

World Take Good Notice (BWP) (DT44)

O Tan-Faced Prairie-Boy

Look Down Fair Moon

demobilization and reunification:
Reconciliation
How Solemn as One by One
As I Lay with My Head in Your Lap Camerado (insert from an 1871 "Leaves of Grass" sub- group) (SD10)
Delicate Cluster (BWP)
To a Certain Civilian (AS) (DT28)
Lo, Victress on the Peaks (BWP) (SD16)
Spirit whose Work is Done
Adieu to a Soldier (MWO)
Turn O Libertad (MWO) (DT50)
To the Leaven'd Soil They Trod

Thus we have the empirical and bibliographical evidence that the "Drum-Taps" cluster, as ultimately presented to the world by Whitman, owes its essential structure and meaning to Rossetti's editorial pioneering of 1868 . That Whitman had very early access to Rossetti's anthology is indisputable; we have the poet's enthusiastic letter of March 9, 1868, in which Whitman acknowledges receipt of a copy of the Rossetti selection from the publisher, John Camden Hotten. ${ }^{7}$ Some critics might argue that the "cycle of war" themes apparent in the "Drum-Taps" sequencing were already implicit in the 1865 materials and that Whitman instinctively pulled them together in his later arrangements of 1871 and 1881, but it could not be coincidental that such strong similarities of poem choice and order of placement were taken up by Whitman, as these previously appeared in the 1868 Rossetti anthology. Whether this structural "borrowing" on which Whitman expanded was due to conscious choice or unconscious influence from previous reading of the selection may remain debatable. It should also be borne in mind that authors and poets are not always candid about the sources of their inspiration, a caveat which might usefully apply to those later statements of Whitman in which he generally grumbles about the "expurgation" of his Leaves by Rossetti and others. When Whitman in 1888-twenty years after the fact-declares to Horace Traubel that Rossetti "made Leaves 
of Grass over from a sequential product to a poetic scrap-heap," one suspects a bit of somewhat devious posturing, insofar as Rossetti had followed the exact reverse of this procedure in the editing of his "DrumTaps" cluster, as Whitman must surely have been aware ${ }^{8}$ It is also not curious that Rossetti, a cosmopolite of sophisticated culture and progressive politics, could grasp the poetic vision originally denied Whitman as a person simply too psychically "close" to the Civil War; thus the requisite artistic "distance" necessary for the recognition of Erkkila's "providential" pattern was provided by Rossetti, who gave Whitman and "Drum-Taps" the long-term "view" to an American conflict.

\section{University of Missouri-Columbia}

\section{NOTES}

1 Poems by Walt Whitman: Selected and Edited by William Michael Rossetti (London: John Camden Hotten, 1868). The most comprehensive and detailed study to date of the editorial preparations connected with Rossetti's anthology is found in Morton D. Paley, "John Camden Hotten and the First British Editions of Walt Whitman-'A Nice Milky Cocoa-Nut,"” Publishing History 6 (1979-1980), 5-35.

2 The 1867 Leaves was issued in a variety of binding configurations. The primary issue (upon which Rossetti based his selection) consisted of a "four volumes in one" binding of Leaves proper followed by the original signatures of Drums-Taps/Sequel and concluded by a "pseudo-annex" titled "Songs Before Parting"; see descriptive analysis in Jacob Blanck, Bibliography of American Literature (New Haven: Yale University Press, 1991), 9:34-35, and Joel Myerson, Walt Whitman: A Descriptive Bibliography (Pittsburgh: University of Pittsburgh Press, 1993), 41-48. The 1867 Leaves proper included only three of the six clusters present in the 1860 edition; the bulk of poems, new and old, were amorphously scattered without regard to thematic relations.

3 See her Whitman the Political Poet (New York: Oxford University Press, 1989), 212. The basic thematic sequence described by Erkkila for the 1881 "Drum-Taps" cluster has also been recognized by James E. Miller, Jr., A Critical Guide to Leaves of Grass (Chicago: University of Chicago Press, 1957), 219-225.

4 Anthony Szczesiul likewise notes the marked shift in perspective between.Whitman's 1865 and 1871 organizations of the "Drum-Taps" poems, while also discussing a general "narrative progression" within the 1871 cluster which essentially duplicates Rossetti's thematic sequencing of 1868 to be analyzed here; see his essay, "The Maturing Vision of Walt Whitman's 1871 Version of Drum-Taps," Walt Whitman Quarterly Review 10 (Winter 1993), 127-141.

5 Leaves of Grass: Comprehensive Reader's Edition (New York: New York University Press, 1965), 279n. Further quotations of Bradley and Blodgett refer to this citation.

6 As traditional in Leaves of Grass scholarship, this study will at all points cite poems by their final "definitive" titles, regardless of earlier designations by either Whitman or Rossetti.

7 Whitman to Hotten, The Correspondence: 1868-1875, ed. Edwin Haviland Miller (New York: New York University Press, 1961), 2:21-22.

8 See Horace Traubel, With Walt Whitman in Camden (New York: Mitchell Kennerley, 1914), 3:320. 